\title{
DRUMLINS AND PLEISTOGENE IGE FLOW OVER THE ARDS PENINSULA/STRANGFORD LOUGH AREA, COUNTY DOWN, IRELAND
}

\author{
By Peter Vernon \\ (Department of Geology, The Queen's University of Belfast, Belfast, Northern Ireland)
}

\begin{abstract}
The geographical distribution of the drumlins was studied. They are arranged in bands perpendicular to ice pressure with a weaker alignment parallel to ice flow. An hypothesis of drumlin origin is presented. Two ice flows are present, a strong flow from an Irish centre to the north-west, and a weaker flow of Scottish ice from the north.
\end{abstract}

RÉsumé. Drumlins et écoulement pléistocène de la glace sur la Ards Peninsula, région de Strangford Lough, County Down, Ireland. On a étudié la distribution des drumlins. Ils sont rangés en bandes perpendiculaires à la pression de la glace avec un alignement moins marqué parallèle à l'écoulement de la glace. On peut distinguer deux courants de glace, le plus fort d'un centre irlandais vers le nord-ouest, et un courant plus faible de glace écossaise venant du nord.

Zusammenfassung. Drumlins und Fliessrichtung des Eises im Pleistozän über dem Ards Peninsula/Strangford Lough Gebiet, County Down, Irland. Die geographische Verteilung der Drumlins wurde untersucht. Sie sind in Bändern senkrecht zum Eisschub und in schwächeren Bändern parallel zur Fliessrichtung des Eises angeordnet. Eine These über die Entstehung der Drumlins wird aufgestellt. Es lassen sich zwei Fliessrichtungen feststellen, eine starke aus einem Zentrum in Irland nach Nordwesten und eine schwächere schottischen Eises von Norden.

\section{INTRODUCTION}

The area covered by this study (Fig. I) lies east of long. $5^{\circ} 43^{\prime} \mathrm{W}$. and it is the most easterly part of Ireland. It includes all of the Ards Peninsula east of Bangor and most of Strangford Lough together with some land to the west and south of the lough.

The local bedrock is chiefly Silurian in age with minor Ordovician inliers, a narrow strip of Triassic sandstone along the north-east shore of Strangford Lough being the only postSilurian sediment. The structural trend is Caledonoid (north-east to south-west) throughout the area. The relief is low and, apart from the rocky foreshore, outcrop is scarce.

This area was intensely glaciated during the Midland general glaciation, which is probably of Weichsel age (Farrington, 1949). As a result of glaciation the area is covered by till, often forming drumlins but also occurring as flat areas between drumlins or as hummocky moraine, especially in the exteme north and south of the area.

The drumlins form a belt bounded on the south by a moraine (Fig. I), which has been called the Carlingford re-advance moraine by Charlesworth (I955), who traced it across Ireland from Galway Bay. The author has traced this moraine along the south coast of County Down where it is best shown at Ardglass and Killard Point (Fig. 2).

\section{DrumLins}

Drumlins are smooth elliptical hills which have been compared to inverted spoons. Because of this distinctive shape, a field of drumlins has a characteristic appearance and is known in Ireland as "bag of potatoes" country. Drumlins are elongated in the direction of ice movement, generally with the stoss or front side blunter than the lee or rear side. Along with similar features such as roches moutonnées, crag and tail, whalebacks and other drumlinoid forms, they are streamlined bodies produced under flowing ice. The composition of drumlins is variable and it may consist of rock, drift or any combination of the two (Flint, [1957]).

Drumlins are known from most glaciated areas but they seem typical of the latest glaciation. Few, if any, remain from early glacial periods. As Alden (I9I I) and Taylor (I934) have pointed out, drumlins are characteristic of broad basins, are associated with radial ice flow and occur in wide belts parallel to, but at some distance behind, end moraines. 


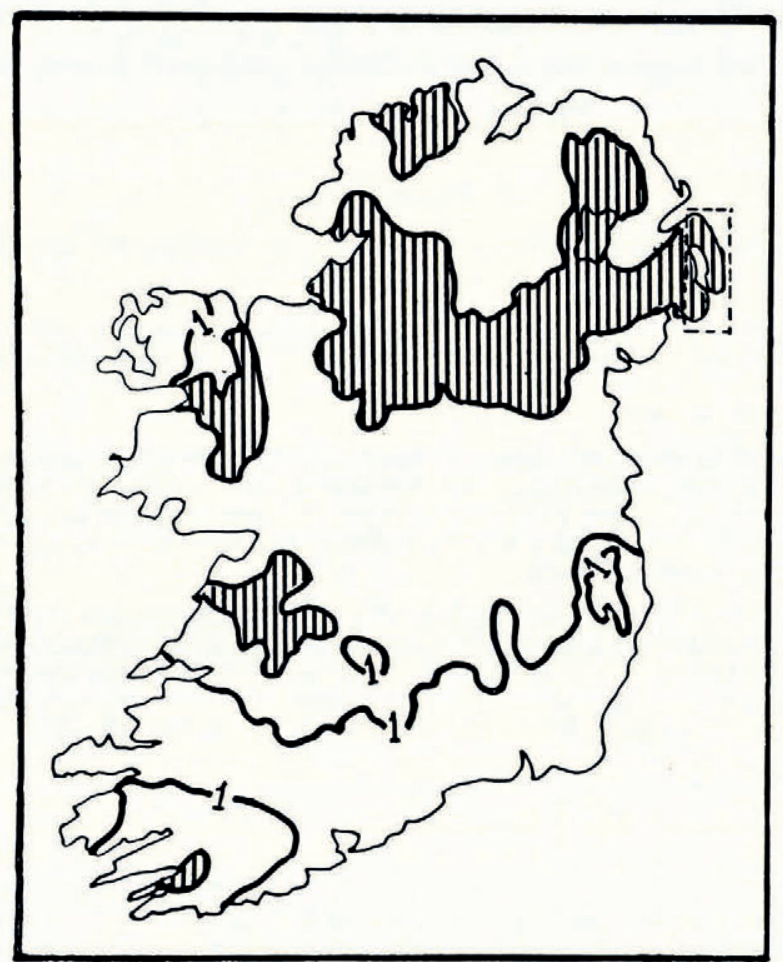

Fig. I. Location of the area (dashed line) and limits of the Midland general (Weichsel) glaciation in Ireland (after Synge and Stevens, 1960$)$

I. Limits of the Midland general glaciation (Weichsel).

2. Drumlin belts (vertical stripes).

This is certainly true in Ireland where the drumlin belt is within and parallel to the Weichsel end moraine (Fig. I).

Drumlins and drumlinoid features are easily recognizable on air photographs because of their peculiar shape. They may, however, be confused with kames, especially if the elliptical shape is not well developed. For this reason, in this study, only those features with a definite elliptical shape were mapped as drumlins.

The bulk of the work was done with I : 20,000 air photographs at the Ordnance Survey of Northern Ireland. The rest was done with I : 9,00o photographs supplied by the Geography Department of The Queen's University of Belfast. The I : 20,00o scale is much to be preferred for geomorphological work as the features are seen much more clearly and the area can be covered by far fewer photographs. After the drumlins were identified on the photographs they were transferred to a base map (scale I : 25,00o) and then reduced to the scale of Figure 2a.

A total of 873 drumlins was recognized, 6r 3 on Ards Peninsula, I35 on the west side of Strangford Lough and 56 on the south side of the lough. 69 drumlins are drowned in the lough but are still recognizable as drumlins.

\section{Alignment of the drumlins and ice flow}

The ice flow indicated by the drumlin alignment is somewhat complex. Two converging flows are indicated, consisting of a dominant flow from the north-west which meets and diverts a second flow from the north. This flow pattern is substantiated by the striae and 


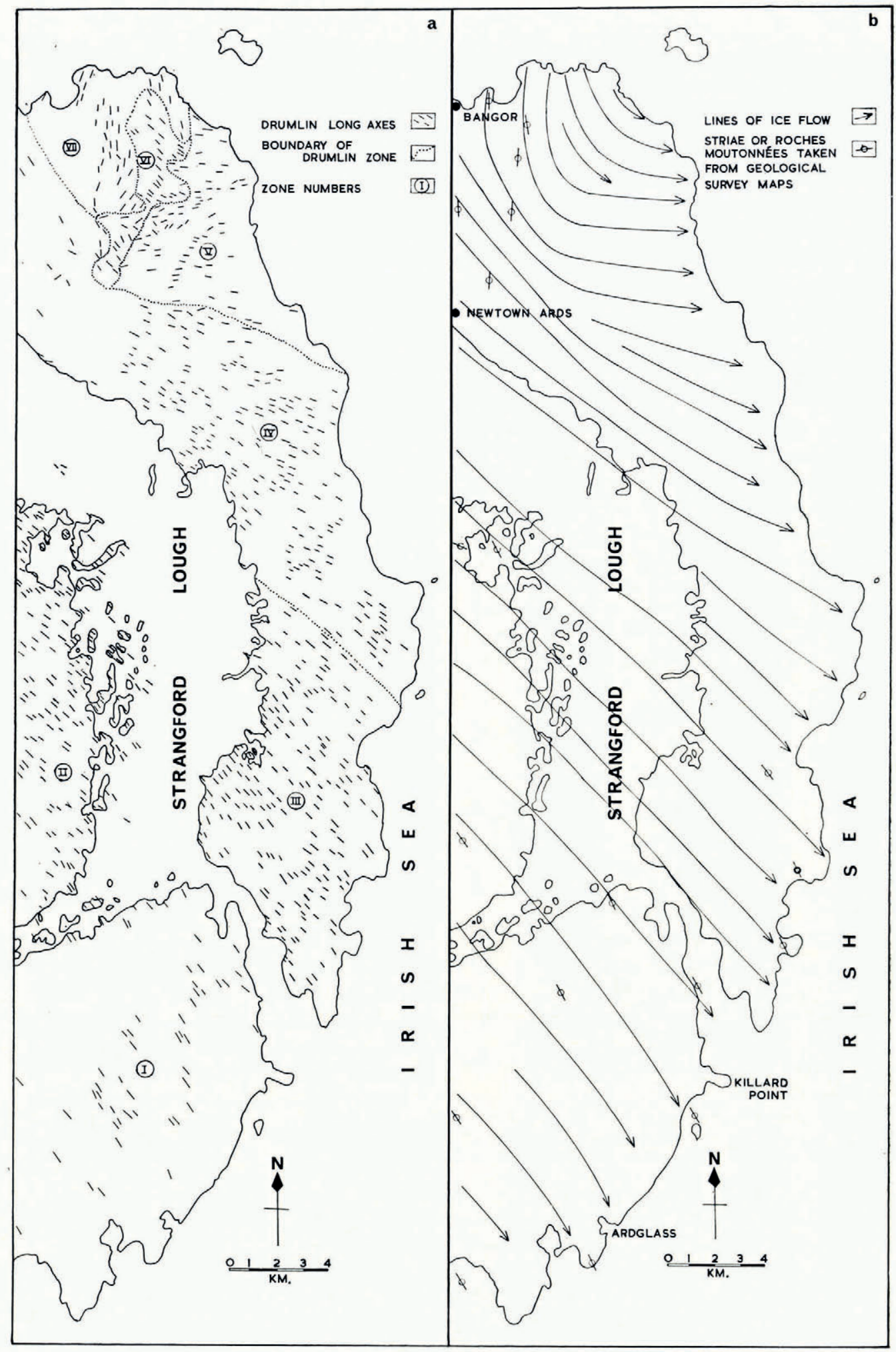

Fig. 2. Drumlins and ice flow in the Ards Peninsula/Strangford Lough area, County Down a. Drumlins and drumlin zones.

b. Lines of ice flow derived from Figure $2 a$. 
roches moutonnées marked on the Geological Survey of Ireland maps* of the area (Fig. $2 \mathrm{~b}$ ). Because of the differing flow directions, it is possible to outline zones of drumlins of similar alignment by inspection. These zones are arbitrary but they serve to aid discussion of different parts of the area (Fig. 2). The two zones on the south and west of the lough (zones I and II) are distinguished by geographic isolation rather than by differences in drumlin alignment.

The flow within the zones is quite distinct; in zones I, II and III the flow is similar. Ice moved from the north-west and most of the drumlins trend between $130^{\circ}$ and $150^{\circ}$. In zone IV, flow was from between $100^{\circ}$ and $130^{\circ}$. In zone $\mathrm{V}$ ice moved directly from west to east, and in VII from north to south. Zone VI is transitional between zones V and VII (Fig. 2).

\section{Size and shape of drumlins}

Of the total of 873 drumlins recognized on air photographs, 786 were measured; the remainder were not measured as they are either drowned in Strangford Lough or have been so modified by wave action at the present or earlier sea-levels that their true shape is not discernible.

On each drumlin the long and the short axes were measured, and the ratio of the length (long axis) to the breadth (short axis) was calculated. The means and the standard deviations $(\sigma)$ of the axial lengths and the ratios were determined on the Deuce Calculator of the Department of Applied Mathematics, The Queen's University of Belfast.

The mean length is $308 \mathrm{~m}$; $\sigma=95 \mathrm{~m}$.

The mean breadth is $155 \mathrm{~m}$; $\sigma=4^{1} \mathrm{~m}$.

The mean axial ratio is $2 \cdot 03 ; \sigma=0 \cdot 5^{6}$

Table I gives the means for the area and for the zones.

\begin{tabular}{cccc}
\multicolumn{4}{c}{ TABLE I } \\
Zone & Length & Breadth & Ratio \\
& $\mathrm{m}$. & $\mathrm{m}$. & \\
I & 333 & 177 & $\mathrm{I} \cdot 87$ \\
II & 334 & 137 & $2 \cdot 43$ \\
III & 354 & 167 & $2 \cdot 12$ \\
IV & 322 & 172 & $\mathrm{I} \cdot 88$ \\
V & 236 & 128 & $\mathrm{I} \cdot 84$ \\
VI & & & \\
VII & 268 & 155 & $\mathrm{I} \cdot 73$
\end{tabular}

Charlesworth (1939, p. 262-63) and Ebers (1926; quoted by Charlesworth (1939)) collected drumlin dimensions from the literature, and reported that the average drumlin was less than $\mathrm{I} \mathrm{km}$. long, although the length varied from $30 \mathrm{~m}$. to $15 \mathrm{~km}$. The breadth ranged from $50 \mathrm{~m}$. to $800 \mathrm{~m}$. but was usually less than $600 \mathrm{~m}$; 住 I : I to I3: I, the most common being $2:$ I or $3:$ I.

Charlesworth (1939) also measured the drumlins of Ards Peninsula and found a mean length of $420 \mathrm{yd}$. (384 m.), a breadth of $245 \mathrm{yd}$. (224 m.) and an axial ratio of I.7 : I. While these measurements differ from those of the present study, they are within the limits of standard deviation of the data.

\section{Drumlin distribution}

There are two types of drumlin distribution to be considered. The first is the density of drumlins per unit area on the ground; the second is the spacing of drumlins, that is, the relation of one drumlin to its neighbours.

The density of the drumlins was studied by dividing the $\mathrm{I} \mathrm{km}$. squares of the Irish grid into four squares of $0.5 \mathrm{~km}$. by $0.5 \mathrm{~km}$. and counting the number of drumlins

* One inch map sheets Nos. 28, 29, 36, 37, 38, 49, 50 and $6 \mathrm{r}$. 
in each square. The resulting density pattern was then contoured and is shown in Figure 3 .

The density pattern on Figure 3 shows that the drumlins are concentrated in bands both perpendicular and parallel to ice flow. In zones I, II and III the ice flow may be considered to have been uninterrupted and the strongest concentration of linear groups is perpendicular to the ice flow, with less developed bands parallel to the flow. The distance between lines is about $3 \mathrm{~km}$.

The flow is disturbed in the northern zones and the density pattern reflects this disturbance. In zone IV the strongest concentration is parallel to both the ice flow and to the zone boundaries, probably as a result of pressure from the Scottish ice moving in from the north and being diverted eastwards (Fig. 3). The pattern in the northern zones (V, VI and VII) is dominantly radial, thus remaining perpendicular to the swinging ice flow.

The drumlins often tend to occur together, usually in en échelon groups. Most, however, ( I 14, or I9 per cent in the present study) occur singly with no obvious relationships to others. Groups of two make up I 3 per cent ( $=84$ drumlins) of the total; the remainder are disposed in groups of up to 40 . Only the 733 drumlins readily identified on land were used.

The spacing of the drumlins was studied by measuring the angle between the ice flow (long axis of drumlins) and a line joining the centres of adjacent drumlins (Fig. 4a). This angle, together with the length of the line was used with a traverse table to determine the spacing perpendicular and parallel to the ice flow. The results are presented in Figure 4 . The line joining the centres of adjacent drumlins makes various angles with the line of ice flow (elongation of drumlins); the commonest is $0^{\circ}$, the next commonest is $90^{\circ}$, with all gradations between. Angles in the right-hand quadrant (facing the ice flow) are commoner than those in the left (Fig. 4b).

The spacing of drumlins is also variable; the mean distance between drumlin centres is about $335 \mathrm{~m}$. (Fig. 4c). The mean distance between drumlin centres measured parallel to the ice flow is about $240 \mathrm{~m}$. (Fig. 4d) and the mean distance perpendicular to the ice flow is about $176 \mathrm{~m}$. (Fig. 4d). Reed and others (1962) found that in New York these distances were $2,280 \mathrm{ft}$. $(695 \mathrm{~m}$.) parallel to the ice flow and $\mathrm{I}, 54 \mathrm{oft}$. (469 m.) perpendicular to the ice flow.

\section{Discussion}

Ice flow

The ice-flow pattern established by this study is that of a dominant flow from the northwest. This can only have been Irish ice flowing from a centre over Lough Neagh. The lesser flow of ice from a northerly direction may have come from a Scottish source. This picture is radically different from that given by Dwerryhouse (1923) and Charlesworth (I939), both of whom postulated a dominance of Scottish ice over north-east Ireland.

Dwerryhouse was the first to postulate a strong flow of Scottish ice over eastern Ireland. He reached this conclusion mainly from a study of indicators (chiefly Scottish). There are, however, some contradictions in his evidence. He cited the case of the Scrabo Hill dolerite (Dwerryhouse, I923, p. 396) which was carried south-eastwards, but he did not comment on the fact that this implies a movement of ice from the north-west. He also stated that the striae everywhere support a southward movement of ice down Strangford Lough; in fact, the striae recorded on the Geological Survey maps indicate movement from the north-west, except in the area north of Newtownards where they do trend north-south.

Charlesworth (1939) reproduced Dwerryhouse's ice-flow diagrams without change, and his map of the drumlins of north-east Ireland shows a general south-south-easterly trend over the Ards Peninsula/Strangford Lough area. He did not apparently recognize either the east-west drumlins of zone V or the north-south drumlins of zones VI and VII. This may have been due to the difficulty of determining the true elongation of drumlins without 


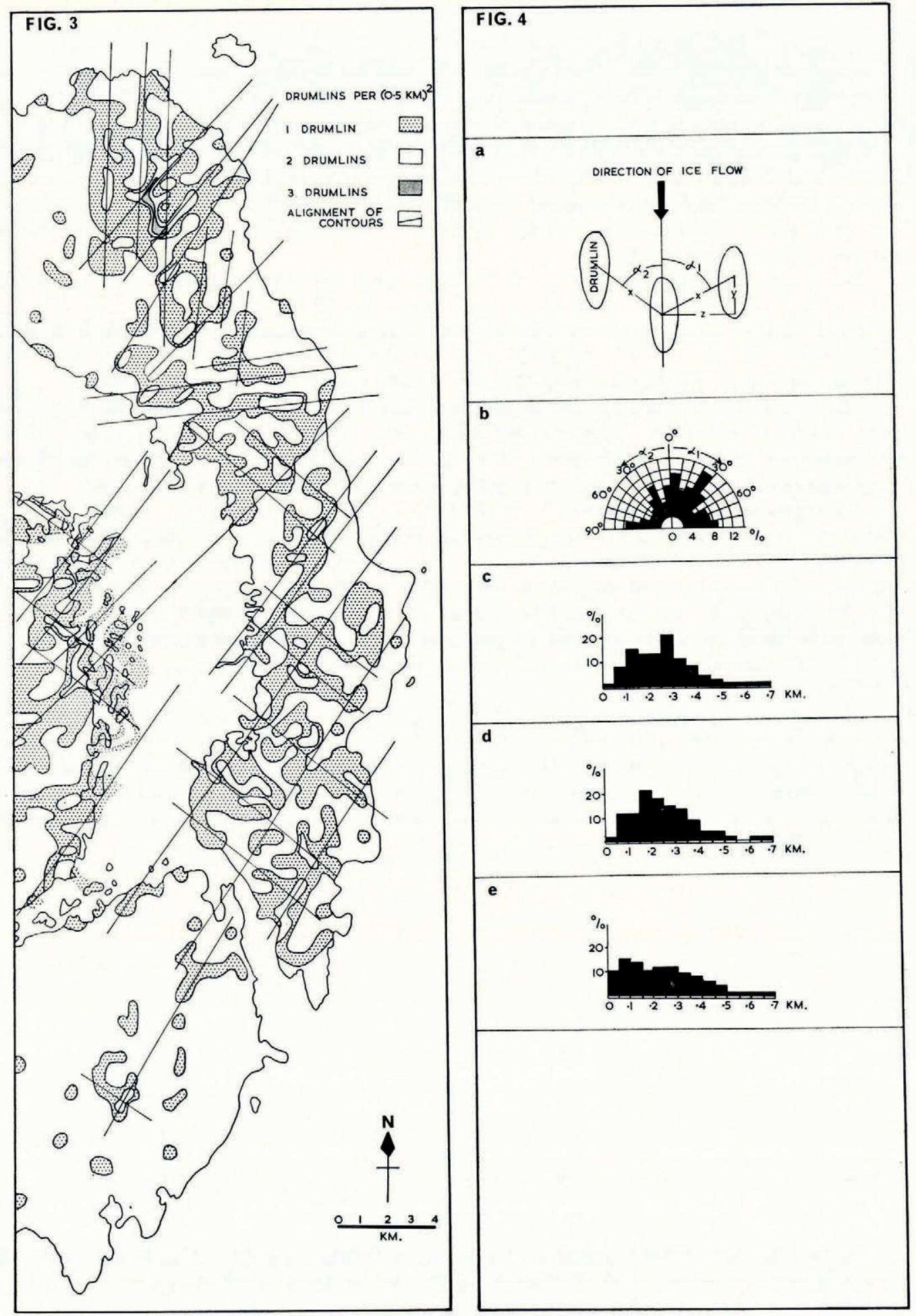

Fig. 3. Drumlin density

Fig. 4. The spacing of drumlins

a. Explanation of measurements. $\alpha_{\mathrm{I}}$ is the angle between a line joining drumlin centres and the line of ice flow, measured clockwise. $\alpha_{2}$ is the same angle counter-clockwise. $x$ is the distance between the centres of adjacent drumlins. $y$ is the distance between drumlin centres measured parallel to the ice flow. $z$ is the distance between drumlin centres measured perpendicular to the ice flow.

b. Rose diagram of angles $\alpha_{1}$ and $\alpha_{2}$.

c. Histogram showing variation in $x$.

$d$. Histogram showing variation in $y$.

$e$. Histogram showing variation in $z$. 
air photographs, especially if, as in zones V and VI, the drumlins are not markedly elongated.

The drumlins, the striae and the carriage of Scrabo Hill dolerite all indicate a strong flow of Irish ice over north-east Ireland at least during the drumlin forming stage of the late glacial period. Scottish ice, if present at all, was present only on the north of Ards Peninsula. This supports the view of Synge and Stevens (1960) that the flow of Scottish ice over Ireland at this time was much weaker than had been supposed.

\section{Drumlin origin}

The typical smooth elliptical form of drumlins is a streamlined shape similar to that of objects designed to pass through a medium (or to allow a medium to flow past the object) with least disturbance (Chorley, 1959). The surfaces of such objects (for example, air foils, birds, fish, etc.) are smooth with no breaks to allow eddy formation or to cause drag. Because of this shape and because of the parallelism of long axes with ice flow, drumlins are accepted as forming beneath flowing ice.

Drumlins are one of a group of streamlined forms described as "ice-moulded". Also in this group are subglacial ridges (Dyson, 1952), which are relatively long compared to their height and breadth; subglacial ridges are usually $200 \mathrm{~m}$. long by $0.5 \mathrm{~m}$. high. These forms are produced by an extrusion process, in which plastic, waterlogged till beneath a glacier is squeezed up into grooves in the base of the ice. The grooves are probably formed by a rock knob or a boulder projecting upwards into the ice from the floor. The flowing ice moulds itself to the obstacle, due to the pressure on the stoss side, but it does not flow back into the space behind the obstacle; thus a cavity is left which is filled with till and is gradually elongated as the ice flows on. This process has been observed in the case of subglacial ridges which often have boulders at their up-stream ends. Ice-moulding around an obstacle, leaving a cavity behind, has been observed by Carol (1947) who managed to descend a crevasse and reach a roche moutonnée on the floor of an active glacier. He observed that ice flow in a zone just above the rock surface was much faster than either the main ice flow or the flow in the ice adjacent to the rock. Carol reasoned that this fast-moving ice was made more mobile by pressure-melting and moved from a high pressure in front of the roche moutonnée to a zone of low pressure behind it.

Hoppe (195I) suggested an extrusive origin for drumlins; till is assumed to have been squeezed up into hollows or caves in the base of a decaying glacier, which then became reactivated and overrode the mass of till.

Gravenor (I 953), Kupsche (I 955) and others have found stratified fluvio-glacial materials within drumlins. Gravenor suggested that drumlins formed by a combination of erosion and deposition following a re-advance over moraine and outwash.

Some drumlins consist entirely of rock and are similar to whaleback ridges and roches moutonnées; others have partial or complete rock cores. Crosby (1934) found that drumlins near Boston, Massachusetts, were of this type. Such forms must be wholly erosional if entirely formed of rock. When a rock core is present it is usually at or near the stoss end (front) of the drumlin (Flint, [1957], p. 68) and is thus analogous to the boulder at the head of subglacial ridges, or to crag and tail.

Alden (I9II) and Taylor (I93I) pointed out that drumlins tended to form in places where the ice flow was radial or dispersive. Alden suggested that such flow would contain areas of low pressure that might be favourable to drumlin development.

One feature that might indicate ice conditions is the size and shape of drumlins. Wright (I9I2) observed that in Donegal the largest and most elongated drumlins occurred in areas of strong unidirectional ice flow. This is true of the Ards Peninsula/Strangford Lough area, the smallest and least elongated drumlins being located in zones V, VI and VII (Table I), where the southward-moving Scottish ice met and was diverted by the stronger Irish ice 
flowing from the north-west, while the largest and most elongated drumlins are found in the zones where the flow is undisturbed.

One factor that seems necessary to drumlin development is the presence of some obstacle to ice flow (such as a hummock) on the floor of the glacier. This hummock may be a rock knob, a large boulder or a group of boulders, till squeezed up into holes in the basal ice, or outwash fillings in crevasses or moulins. In the case of till or outwash, this material must have accumulated during a period of ice stagnation and then been frozen and overridden by a re-advance of the ice. Rock knobs or frozen drift, when overridden create a pressure difference between the front and the back of the obstacle, the high pressure on the front encourages pressure-melting of the ice, thus making it more mobile. The mobile ice moves from high to low pressure more quickly than its load of debris; thus a zone of debris accumulates near the obstacle and is deposited as lodgment till. Drumlins therefore grow by deposition on the stoss and top sides and continue to grow as long as the pressure due to flow is great enough to cause pressure-melting on the front of the drumlin. This process would be encouraged by pressure differences produced by other phenomena such as those suggested by Alden or Taylor.

The drumlins are densest in bands perpendicular to the ice flow in zones I, II, III and IV (Fig. 3); it is possible that this represents waves in the ice forming belts of low pressure favourable to drumlin formation.

\section{Conclusions}

I. There were two ice flows meeting on the north end of Ards Peninsula. Scottish ice from the north advanced over the northern part of the peninsula where it met, and was diverted by, a stronger flow of Irish ice from a source in the Lough Neagh basin to the north-west.

2. Drumlins are concentrated in belts perpendicular to ice pressure. This possibly represents a form of wave phenomena in the ice set up by pressure caused by obstacles or the interaction of different ice flows.

3. Drumlins form when ice flow induces a pressure differential between the front and back of an obstacle. Pressure-melting on the front of the obstacle creates a zone of greater mobility in the ice, which moves to the zone of low pressure behind the obstacle, leaving the debris behind as till.

\section{Acknowledgements}

I wish to thank Dr. W. Schwarzacher and Mr. F. M. Synge, who discussed and encouraged the work, and Professor A. Williams and Dr. A. D. Wright, who critically read the manuscript. Thanks are also due to the Director and staff of the Ordnance Survey of Northern Ireland who lent photographs and facilities without which the study would have been impossible.

\section{MS. received ${ }_{15}$ December 1964 and in revised form 29 December 1965}

\section{REFERENGES}

Alden, W. C. 1911. Radiation of glacial flow as a factor in drumlin formation. Bulletin of the Geological Society of America, Vol. 22, p. 733-34. [Abstract.]

Carol, H. 1947. The formation of roches moutonnées. Journal of Glaciology, Vol. 1, No. 2, p. 57-59.

Charlesworth, J. K. 1939. Some observations on the glaciation of north-east Ireland. Proceedings of the Royal Irish Academy, Vol. 45, Sect. B, No. I 1, p. 255-95.

Charlesworth, J. K. I955. The Carlingford readvance between Dundalk, Co. Louth, and Kingscourt and Lough Ramor, Co. Cavan. Irish Naturalists' Journal, Vol. i I, No. I I, p. 299-303. 
Chorley, R. J. 1959. The shape of drumlins. Fournal of Glaciology, Vol. 3, No. 25, p. 339-44.

Crosby, I. B. 1934. Evidence from drumlins concerning the glacial history of Boston basin. Bulletin of the Geological Society of America, Vol. 45, No. I, p. 135-57.

Dwerryhouse, A. R. 1923. The glaciation of north-eastern Ireland. Quarterly Journal of the Geological Society of London, Vol. 79, Pt. 3, p. 352-42 I.

Dyson, J. L. 1952. Ice-ridged moraines and their relation to glaciers. American Journal of Science, Vol. 250, No. 3, p. 204-I I.

Ebers, E. ${ }_{1926}$. Die bisherigen Ergebnisse der Drumlinforschung. Eine Monographie der Drumlins. Neues Jahrbuch für Mineralogie, Geologie und Paläontologie. Beilagebände, 53, Abt. B, p. I53-270.

Farrington, A. 1949. The glacial drifts of the Leinster Mountains. Fournal of Glaciology, Vol. I, No. 5, p. $220-25$.

Flint. R. F. [1957.] Glacial and Pleistocene geology. New York, John Wiley and Sons, Inc.

Gravenor, C. P. 1953. The origin of drumlins. American Journal of Science, Vol. 251, No. 9, p. 670-81.

Hoppe, G. r95I. Drumlins i nordöstra Norrbotten. Geografiska Annaler, Årg. 33, Ht. 3-4, p. 157-65.

Kupsch, W. O. 1955. Drumlins with jointed boulders near Dollard, Saskatchewan, Canada. Bulletin of the Geological Society of America, Vol. 66, No. 3, p. 327-37.

Reed, B., and others. 1962. Some aspects of drumlin geometry, by B. Reed, C. J. Galvin, Jr., and J. P. Miller. American Journal of Science, Vol. 26o, No. 3, p. 200-10.

Synge, F. M., and Stevens, N. 1960. The Quaternary period in Ireland, an assessment. Irish Geography, Vol. 4, No. 2, p. $121-30$.

Taylor, F. B. 1931. Distribution of drumlins and its bearing on their origin. Bulletin of the Geological Society of America, Vol. 42, No. I, p. 201. [Abstract.]

Wright, W. B. 1912. The drumlin topography of south Donegal. Geological Magazine, New Ser., Vol. 9, No. 4, p. ${ }^{5} 53-59$. 